\title{
Root-restricting layers in German agricultural soils. Part I: extent and cause
}

\author{
Florian Schneider • Axel Don (1)
}

Received: 14 February 2019/Accepted: 18 June 2019/Published online: 13 July 2019

(C) The Author(s) 2019

\begin{abstract}
Aims Root-restricting layers pose a barrier to vertical root elongation. The German Agricultural Soil Inventory was used to assess the extent, cause and effect of root-restricting layers in German agricultural soils.

Methods The following causes for root restriction were considered: bedrock, rock fragments, cementation, compactness, sandy subsoil, anoxia and acidity. Threshold values for restricted root growth were extracted from the literature and validated using root counts of winter wheat and permanent grassland. The effect of management-induced compaction in cropland was quantified using machine learning.

Results In $71 \%$ of all agricultural soils, potential rooting was restricted to less than $100 \mathrm{~cm}$ depth. Compactness was the most common cause of root restriction, affecting $51 \%$ of cropland and $32 \%$ of grasslands. It was estimated that agricultural management explained $27 \%$ of all compacted cropland, while the remaining $73 \%$ has always been compacted as a result of pedogenic causes. Root-restricting soil layers decreased the yield of winter wheat significantly.
\end{abstract}

Responsible Editor: W Richard Whalley.

Electronic supplementary material The online version of this article (https://doi.org/10.1007/s11104-019-04185-9) contains supplementary material, which is available to authorized users.

F. Schneider · A. Don $(\bowtie)$

Thünen Institute of Climate-Smart Agriculture, Bundesallee 65, 38116 Braunschweig, Germany

e-mail: axel.don@thuenen.de
Conclusions In view of potential rooting being restricted on more than half of Germany's agricultural land and this study's results suggesting that root-restricting soil layers have a direct impact on crop yield, there is considerable potential in the melioration of affected sites.

Keywords Compaction · Plough pan · Hardpan .

Rooting depth $\cdot$ Subsoil $\cdot$ Random Forest

$\begin{array}{ll}\text { Abbreviations } \\ \text { PD } & \text { packing density } \\ \text { RMSE } & \text { root mean square error } \\ \text { RRLs } & \text { root-restricting soil layers } \\ \mathrm{R}^{2} & \text { coefficient of determination } \\ \text { SOC } & \text { soil organic carbon }\end{array}$

\section{Introduction}

Root-restricting soil layers (RRLs) pose a barrier to vertical root elongation, which can severely hamper the production capacity of agricultural land. Barriers for root elongation can make cultivated plants more susceptible to drought (limited nutrient and water acquisition) and toppling (reduced anchorage) or cause stunted growth in sugar beet (Beta vulgaris L.) and other root/tuber crops.

In soil without RRLs, subsoil resources have been shown to be of great importance for crop productivity: plant-available water stored in the subsoil can mitigate drought stress long after topsoils have dried out 
(Barraclough et al. 1989; Kirkegaard et al. 2007). Subsoils also store nutrients that may contribute to plant nutrition (Kautz et al. 2013). This is especially true for mobile nutrients such as nitrate, which quickly leach below the topsoil after applications of mineral fertiliser or mineralisation of organic matter (Dunbabin et al. 2003; Lynch 2013). For loess soils in central Germany, Kuhlmann et al. (1989) documented that up to $75 \%$ of total nitrogen uptake in winter wheat (Triticum aestivum L.) is derived from the subsoil. Subsoil resources can buffer yield losses if topsoil resources are temporarily or chronically not available. Thus the importance of accessible subsoil water and nutrients to plant nutrition is elevated during droughts (Kirkegaard et al. 2007; Lynch 2013) and in low-input cropping systems (Kuhlmann and Baumgärtel 1991). RRLs render these additional water and nutrient resources unavailable.

In temperate agro-ecosystems, rootability, i.e. the potential of roots to elongate in soil, is often physically and/ or chemically constrained (Jin et al. 2017; Lynch and Wojciechowski 2015). For example, acidity and waterlogging-induced anoxia can severely hamper root growth. Apart from these chemical restrictions to root growth, rock fragments impose a common physical obstacle for root elongation of annual plants (Kutschera et al. 2009). Rock fragments force plant roots to adopt circuitous vertical growth, and thus incur higher metabolic costs in reaching subsoil resources compared to sites with fine soil only. Babalola and Lal (1977) estimated that the negative effects of rock fragments on root elongation outweigh the positive effects of gravel content, such as enhanced water infiltration and aeration, if the gravel content is above 10-20 vol-\%. Valentine et al. (2012) proposed soil strength to be the dominant limitation for root elongation in UK agricultural soils. Soil strength, which is sometimes also called mechanical impedance, characterises the resistance of the soil matrix against deformation (Lynch et al. 2012). Fusing of soil particles, for example with silica, iron oxides or calcium carbonate, can lead to cemented pans during pedogenesis (van Breemen and Buurman 1998). Such cemented pans exhibit high soil strength and therefore restrict rooting into the subsoil. In unconsolidated soil, soil strength largely depends on bulk density, texture and water content. Bulk density and texture can be used to calculate packing density (PD), which describes the apparent compactness of soils better than bulk density alone (Daddow and Warrington 1983; Huber et al. 2008; Jones 1983; Renger et al. 2014). Increasing PD retards root growth
(Tardieu 1994), although some roots might still be able to penetrate densely packed soil by elongating through structural cracks and biopores (Stirzaker et al. 1996). Seasonal changes in soil water content also exhibit a great influence on soil strength. Dry soils tend to be hard because capillary bridges between soil particles induce tensile forces (Bengough et al. 2011; Kolb et al. 2017; Lynch et al. 2012). This explains why soil strength can change drastically across both space and time. In coarsetextured subsoils, however, the influence of water on soil strength seems less important. Here, sand particles tend to be rigidly embedded and interlocked, which induces a high soil strength despite relatively high macroporosity (Lipiec et al. 2016). The interlocked bedding of rough sand grains may explain the commonly observed shallower rooting depths in coarse sandy compared to loamy soils (Batey and McKenzie 2006; Cruse et al. 1980; Lipiec et al. 2016; Madsen 1985).

Apart from pedogenic and geogenic causes, RRLs can also form due to agricultural management. Numerous studies assume that the soil strength of central European cropland has increased in recent decades because of traffic-induced soil compaction (Håkansson and Reeder 1994; van Ouwerkerk and Soane 1994). This assumption is supported by significant increases in the weight of farm machinery during the past decades. For example, Schjønning et al. (2015) estimated the weight of fully loaded combine harvesters to have increased about sixfold, from $4 \mathrm{Mg}$ in 1958 to $25 \mathrm{Mg}$ in 2009. Also, direct wheeling on top of the subsoil during ploughing operations has been identified as a particularly harmful management practice because compacted subsoil is beyond the reach of annual mechanical loosening operations (tillage). Nevertheless, such in-furrow ploughing has been common practice during ploughing operations all over central Europe. In the early 1990s, Oldeman et al. (1991) estimated that 33 million ha of agricultural land in Europe was degraded because of traffic and ploughing-induced soil compaction. This corresponds to about $4 \%$ of total agricultural land. In Germany, about 10-20\% of cropland has recently been classified as anthropogenically compacted, based on expert judgments (UBA 2018). However, data availability to quantify the extent of compacted subsoils beyond field scale has been scarce, and therefore the numbers quoted above are highly debated (Vorderbrügge and Brunotte 2011). The controversy in quantifying the regional extent of compacted farmland revolves around the choice of appropriate indicators and threshold values 
to demarcate compacted from non-compacted soil, and the representativeness of available measurements for the region of interest. In the past few decades, new agricultural technologies have emerged that help to prevent soil compaction despite high wheel loads, e.g. automatic tyre pressure control systems and out-furrow ploughing (Chamen et al. 2003; Tullberg 2018). Furthermore, farmers' awareness of compaction has risen and many farmers who are aware of the compaction problem avoid trafficking wet soil today (Batey 2009). Thus, the extent of compacted European cropland today is still unknown.

In Germany, $70.6 \%$ of agricultural land is used for annual crops, $28.1 \%$ for permanent grassland and $1.2 \%$ for perennial crops such as vineyards (Destatis 2017b). Only about $3 \%$ of agricultural land is irrigated (Destatis $2017 \mathrm{c}$ ). Thus the vast majority of farmed land is rainfed. Annual crops are dominated by winter wheat, with $25 \%$ of cropland cultivation. In recent decades, dry spells have caused increasingly severe yield losses in winter wheat (Lüttger and Feike 2018). In 2018, yield losses due to drought were particularly pronounced, with the yield of winter wheat growing in northeast Germany $26 \%$ lower than the decadal average (Statistisches Amt Mecklenburg-Vorpommern 2018). In the future, dry spells are likely to be amplified due to greenhouse gasinduced global warming (Pfeifer et al. 2015). Thus deep rootability and the associated availability of subsoil water will be of increased importance in mitigating drought stress. However, little is known about the extent of RRLs in Germany. The present study used the first German Agricultural Soil Inventory to examine soil compactness and other RRLs at national scale. Specifically, the objectives of this study were:

(i) to characterise the extent and distribution of RRLs in agricultural land in Germany

(ii) to estimate their effect on root growth and crop yield, and

(iii) to quantify the effect of land use and management on soil compactness.

\section{Materials and methods}

The German agricultural soil inventory

The dataset of the first German Agricultural Soil Inventory (2011-2018) comprises soil, management and yield data from 3078 sites covering all cropland and cultivated grasslands of Germany in a grid of $8 \mathrm{~km} \times$ $8 \mathrm{~km}$ (Jacobs et al. 2018). At each site, soil profiles were dug down to $100 \mathrm{~cm}$ depth and soil morphology was characterised in accordance with AD-HOC-AG Boden (2005) for each soil horizon. Soil samples were taken at fixed depth intervals $(0-10,10-30,30-50,50-70$ and $70-100 \mathrm{~cm})$. If soil horizons changed between depth intervals ( $>5 \mathrm{~cm}$ above or below sampling thresholds), additional samples were taken in order to match each soil sample with the corresponding soil horizon. All soil samples were analysed for texture, bulk density, soil organic carbon (SOC), inorganic carbon, $\mathrm{pH}$ (1:5 in water) and other physicochemical soil properties (Table S 1; Jacobs et al. (2018)). In all, data from 15,125 soil horizons and 16,778 soil samples were evaluated for this study. All soil analyses were conducted in the same laboratory and all soil horizons were characterised by well-trained experts (eight experts covered $89 \%$ of all sites). Information on crop rotations, yields and management was derived from farmer questionnaires (Table S 1).

\section{Definition of root-restricting soil layers}

The literature was reviewed for soil parameters that have previously been shown to restrict root growth on agricultural land in a temperate climate. The search resulted in a total of seven parameters (Table 1, Fig. S 1). For each parameter, the literature was screened for threshold values beyond which root growth was restricted. If this threshold was unambiguous (e.g. bedrock: no/yes), two levels of root restriction were defined: no root restriction (e.g. bedrock: no) and severe root restriction (e.g. bedrock: yes). If reported threshold values differed, three levels of root restriction were defined: soil layers with parameter values beyond the most extreme threshold value were classified as severely root-restricting, soil layers with parameter values between the least and most extreme reported threshold values were classified as moderately root-restricting, and the remaining soil layers with parameter values below the lowest threshold value were classified as not root-restricting, i.e. lower than moderate or severe root-restriction. Discretizing the degree of root restriction was a necessary simplification because, to the best of our knowledge, no function exists that relates soil properties to root restriction at continuous scale and under field conditions. 


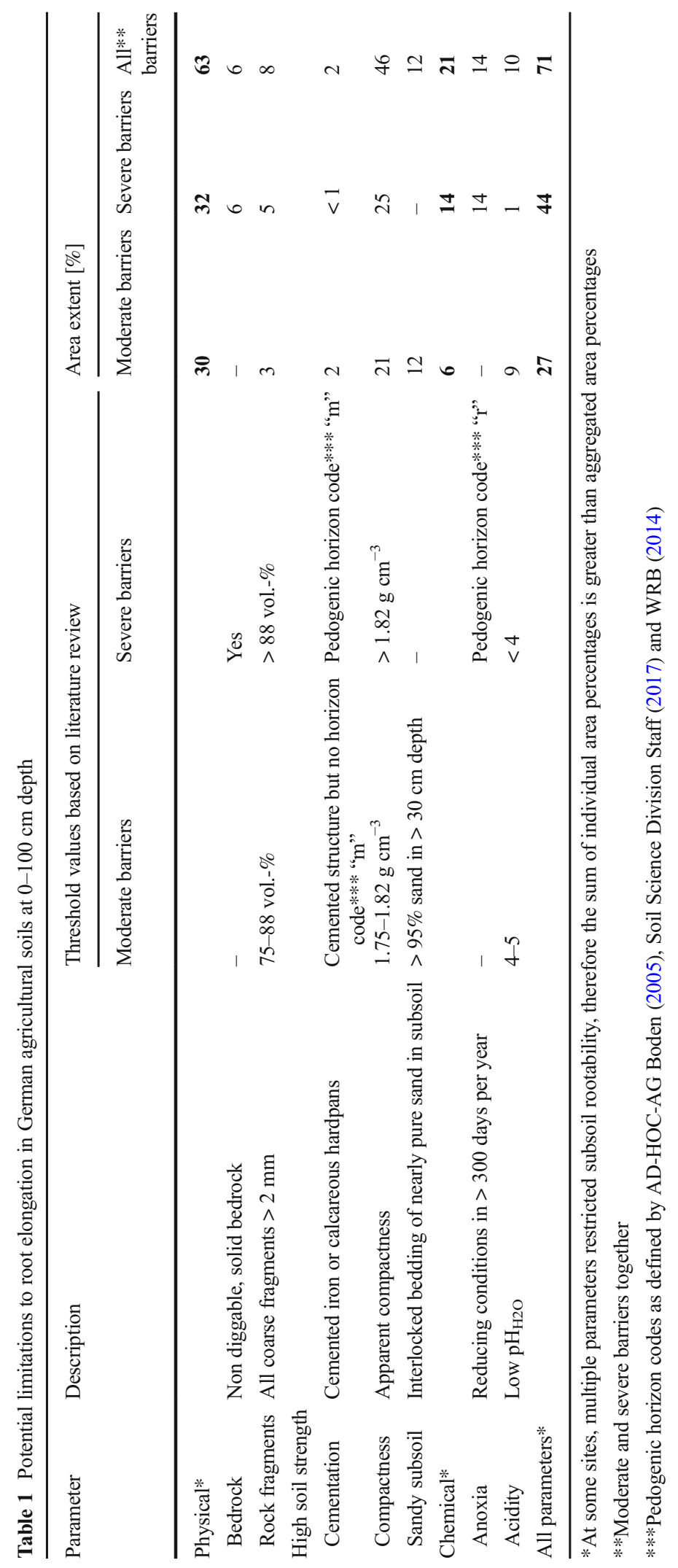


Restricted root elongation due to compactness was evaluated on the basis of PD - a parameter which is in good agreement with other common indices describing the compactness of soils, such as least limiting water range (da Silva and Kay 1997; Kaufmann et al. 2010), S-Index (Dexter 2004; Kaufmann et al. 2010) and degree of compactness (NaderiBoldaji et al. (2016); Fig. S 2). PD was calculated after Renger et al. (2014):

$$
P D=\text { Bulk density }+0.005{ }^{*} \text { clay }+0.001 *^{*} \text { silt }
$$

where both $P D$ and Bulk density are given in $\mathrm{g} \mathrm{cm}^{-3}$, and clay and silt contents are given in mass-\%. Bulk density refers to the dry bulk density of fine soil $(<$ $2 \mathrm{~mm})$ and was calculated as $\left(m_{\text {tot }}-m_{\text {coarse }}-m_{\text {roots }}\right) /$ $\left(V_{\text {tot }}-\frac{m_{\text {caase }}-}{\rho_{\text {coarse }}}-\frac{m_{\text {roots }}}{\rho_{\text {roots }}}\right)$ where $V_{\text {tot }}$ is the volume of an undisturbed soil core in $\mathrm{cm}^{-3}, m_{t o t}$ is its corresponding mass in $\mathrm{g}$ after drying at $105^{\circ} \mathrm{C}$ until constant weight, $m_{\text {coarse }}$ is the dry mass of the coarse fraction $>2 \mathrm{~mm}$ in $\mathrm{g}$, $\rho_{\text {coarse }}$ is the density of the coarse fraction in $\mathrm{g} \mathrm{cm}^{-3}$, $m_{\text {roots }}$ is the dry root mass, and $\rho_{\text {roots }}$ is the density of roots which was assumed to be $1.0 \mathrm{~g} \mathrm{~cm}^{-3}$ (Barber 1995). If field workers estimated $\rho_{\text {coarse }}$ to deviate from normal $\left(2.65 \mathrm{~g} \mathrm{~cm}^{-3}\right), \rho_{\text {coarse }}$ was determined in the laboratory with a particle density determination kit (YDK01, SARTORIUS). Soil cores were usually obtained using sample rings on profile walls. In a few cases, the soil cores were taken with a driving hammer (Walter et al. 2016). Soil texture was measured by sedimentation/pipette method for $97 \%$ of all samples. For the remaining samples, texture was inferred from NIR spectra following Jaconi et al. (2019). Reported threshold values for restricted root growth due to high PD differed. The upper threshold value $\left(1.82 \mathrm{~g} \mathrm{~cm}^{-3}\right)$ was extracted from Kaufmann et al. (2010) while the lower value $\left(1.75 \mathrm{~g} \mathrm{~cm}^{-3}\right)$ was based on Huber et al. (2008). Bedrock was defined as consolidated rock that is not diggable with a spade. Bedrock is widely agreed to restrict root growth and is therefore classified as restricting root growth severely (Schoeneberger et al. 2017). Rock fragment content was determined following the standard procedures of German soil inventories in forestry (GAFA 2014). The content of gravel sized rock fragments (in vol-\%) was calculated as $m_{\text {gravel }}$ $\rho_{\text {gravel }}$. The volumetric fraction of cobbles, stones and boulders was estimated directly in the field and added to the volumetric fraction of gravel. In the literature, reported rock fragment contents beyond which root growth was restricted differed. The most extreme threshold value (88 vol.-\%) was based on Leenaars et al. (2018), while the least extreme threshold value (75 vol.-\%) was extracted from Stahr et al. (2016). Cementation was characterised based on the German classification system for soil horizons (AD-HOC-AG Boden 2005). As per the definition, horizons classified as " $m$ " describe strongly cemented soil layers such as hard iron pans in Podzols, while cemented soil structure ("Kittgefüge") also includes moderate degrees of cementation (e.g. friable iron pans). Therefore, all soil horizons encoded with " $m$ " were classified as severely root-restricting, and all soil layers with a cemented soil structure but without horizon code " $m$ " were classified as moderately root-restricting. Inclusion of sandy subsoil as an indicator of restricted root growth was inconsistent in the literature. For example, the USDA Soil Survey Handbook (Soil Science Division Staff 2017) does not include sandy subsoils as a standalone criteria for restricting root growth, while other handbooks (Mueller et al. 2007) and reviews (Batey and McKenzie 2006) do. Due to the inconsistent reporting in the literature, sandy subsoils were assumed to restrict root growth only moderately. The corresponding threshold value (95\%) was extracted from Leenaars et al. (2018). Owing to ambiguous findings for topsoils (Poeplau and Kätterer 2017), soil layers with $>95 \%$ sand were only classified as moderately root-restricting at $>30 \mathrm{~cm}$ depth. The degree of anoxia was characterised by visual examinations of soil profiles after AD-HOCAG Boden (2005). Soil horizons, in which reducing conditions occurred on roughly $>300$ days per year, were classified as anoxic (pedogenic horizon code " $r$ "). In the literature, anoxia is widely agreed upon as restricting root growth (Soil Science Division Staff 2017). Therefore, anoxic soil layers were classified as restricting root growth severely. Acidity was inferred from $\mathrm{pH}$ measurements in double deionised water ( $5 \mathrm{ml}$ soil in $25 \mathrm{ml}$ water). The reported $\mathrm{pH}$ values beyond which root growth was restricted differed. The lowest value ( $\mathrm{pH} 4$ ) was based on Slattery et al. (1999) and the upper value ( $\mathrm{pH}$ 5) on Lynch and Wojciechowski (2015).

Effect of root-restricting layers on root distribution

The effect of moderate and severe RRLs on subsoil rooting was quantified using root counts from profile 
walls (Fig. S 3). Root counts were originally given in ordinal classes for fine, coarse and unspecified-sized roots (AD-HOC-AG Boden 2005). These classes were converted to a numeric scale based on Table S 2 and the numbers summed to yield root counts per $\mathrm{dm}^{2}$ and soil layer (independent of root size). Root counts from sites (i) without any variation along depth, (ii) with fewer than 4 roots $/ \mathrm{dm}^{2}$ in $0-10 \mathrm{~cm}$, or (iii) with increasing root counts with depth were omitted in order to increase the comparability between sites. As root counts were available only once per site at the time of soil sampling, they referred to different plants (species and cultivars), growing stages, management and growing seasons (weather conditions). This induced considerable variation in the root count data, which was not related to RRLs. In order to still see the effects of RRLs on subsoil rooting, this study (i) restricted the evaluation to roots in permanent grassland and roots of winter wheat (most common crop type), (ii) evaluated all RRLs combined and only the most common cause of root restriction individually (compactness), and (iii) normalised the observed root counts for each site by dividing the root count at a given depth by the root count of the uppermost soil layer (0$10 \mathrm{~cm}$ ). These normalised root counts are referred to below as relative root counts. Basing the analyses on relative instead of absolute root counts increased the comparability of root data between sites. Sites with RRLs in $0-10 \mathrm{~cm}$ depth (5\% of all remaining sites) were excluded from the analysis. The relationship between RRLs and relative root counts was examined by depth (30-50 cm, 50-70 cm and 70-100 cm). This was not done for $10-30 \mathrm{~cm}$ because of the low number of sites with RRLs at this depth. ${ }^{1}$ A given site was classified as root-restricting at depth ${ }_{i}$ if root restriction occurred at or above depth ${ }_{i}$. This was done in order to account for the fact that RRLs (e.g. severely compacted plough pan at $30-50 \mathrm{~cm}$ ) act as a barrier to vertical root elongation into greater depths (e.g. subsoil below the plough pan).

\section{Effect of root-restricting layers on crop yield}

In order to discuss the severity of RRLs, grain yields of winter wheat were compared at sites with and without

\footnotetext{
${ }^{1}$ On global average, German cropland is traditionally ploughed quite deeply. The German Agricultural Soil Inventory revealed Ap-horizons to reach an average depth of $31 \pm 0.1 \mathrm{~cm}$. Therefore, plough pans are typically located below this depth.
}

RRLs in 0-100 cm depth. Winter wheat was selected because this was the most common crop. The comparison was based on multi-annual average yields per site. Only sites with yield data of two or more growing seasons were included (87\% of total cropland). The yield data were derived from farmer questionnaires on crop yields of the sampling sites in the 10 years prior to sampling. Crop yields were compared for all RRLs combined and for compactness, which was the most common RRL on sites used for winter wheat. Yield effects due to compactness were additionally evaluated based on a drought index. If cumulative daily precipitation from April to June (DWD 2019) was below median average (171 mm), the growing season was classified as "dry" and if it was above that value as "wet".

\section{Causes of soil compactness}

The main drivers of the compactness (PD) of German agricultural soils were identified using Random Forest models on each land use (only annual crops, only grassland or all land uses with land use as a predictor variable) and depth category $(0-10 \mathrm{~cm}, 10-30 \mathrm{~cm}, 30$ $50 \mathrm{~cm}, 50-70 \mathrm{~cm}, 70-100 \mathrm{~cm}$ or $0-100 \mathrm{~cm}$ with soil depth as a predictor variable). Random Forest is presently one of the most successful machine learning algorithms (Biau and Scornet 2016), which has proven particularly accurate and robust in predicting soil compactness and other soil properties (Hengl et al. 2017). A wide range of pedology, geology, climate and managementrelated potential predictors of soil compactness were compiled, which partly originated from external sources. A detailed overview of all the input variables is provided in the annex (Table S 1). Since soil compactness does not restrict root growth in peatland and fens, the analyses in this study focused on mineral soils only, i.e. soils containing $<8.7 \%$ SOC (AD-HOC-AG Boden 2005).

Next, the anthropogenic-induced increase in the compactness of mineral soils under cropland use was quantified. In Germany, most cropland receives frequent trafficking with heavy farm machinery, and links between trafficking intensity and subsoil compactness are frequently reported (Schjønning et al. 2015). Furthermore, cropland contains less SOC than soil under potential natural vegetation such as grassland or forest (Poeplau and Don 2013), and soil compactness tends to increase with decreasing SOC 
content (De Vos et al. 2005). However, 93\% of German cropland is regularly ploughed or chiselled (Destatis 2017a), which loosens the soil structure. Thus, it was assumed that the compactness of cropland $\left(P D_{\text {crop }}\right)$ can be described as follows:

$P D_{\text {crop }}=P D_{\text {ref }}+$ use + man

where $P D_{\text {ref }}$ is the theoretical, site-specific PD without anthropogenic influence, use describes the land useinduced change in compactness due to SOC losses after conversion to cropland, and man describes management-induced change in compactness due to trafficking/tillage. As grassland is not ploughed (no plough pan) and typically receives a lower trafficking intensity than cropland, it was assumed that

$P D_{\text {ref }} \approx P D_{\text {grass }}$

where $P D_{\text {grass }}$ is the site-specific PD under permanent grassland use. To quantify man, a Random Forest model was therefore trained only on data from permanent grassland (0-100 $\mathrm{cm}$ with soil depth as the predictor variable) and used to predict the $\mathrm{PD}$ of cropland as a function of depth $\left(\widehat{P D}_{\text {crop }}\right)$. Only grassland without landuse conversions in the previous 30 years was included in the model training in order to omit possible cases of historic plough pans in grassland. If no information on land-use history was provided in the farmer questionnaires, sites were only included if soil profiles did not show relictic plough horizons. Owing to the nature of available input variables, the grassland model accounted for a wide range of pedogenic, geogenic and SOC (use) effects on $P D_{\text {crop }}$, but was not informed about tillage practices and the hypothesised greater trafficking intensity on cropland (man) compared to grassland:

$\widehat{P D}_{\text {crop }}=P D_{\text {crop }}-$ man

Rearranging Eq. 4 gives

man $=P D_{\text {crop }}-\widehat{P D}_{\text {crop }}$

Hence, man could be quantified by calculating the residuals of $\widehat{P D}_{\text {crop }}$ (Fig. 1, triangles). However, the grassland model used to predict $\widehat{P D}_{\text {crop }}$ slightly overestimated measured PD in 10-30 $\mathrm{cm}$ and 70$100 \mathrm{~cm}$ depth (Fig. 1, circles). Therefore, man was quantified by comparing the residuals of $\widehat{P D}_{\text {crop }}$ with the residuals of the out-of-bag estimates for
PD in grassland $\left(P D_{\text {grass }}-\widehat{P D}_{\text {grass }}\right)$ and Eq. 5 was corrected accordingly:

man $=\left(P D_{\text {crop }}-\widehat{P D}_{\text {crop }}\right)-\left(P D_{\text {grass }}-\widehat{P D}_{\text {grass }}\right)$

If the residuals of cropland were higher than in grassland, this was interpreted as increasing compactness due to trafficking (Fig. 1, yellow area). In order to quantify use, the site and depth-specific SOC deficit due to cropland use was estimated first. This was done by comparing the SOC contents of cropland and grassland from paired plots, which were examined by Poeplau and Don (2013) in a previous study. In 0$10 \mathrm{~cm}, 10-30 \mathrm{~cm}, 30-50 \mathrm{~cm}$ and $50-100 \mathrm{~cm}$, grassland had a 2.29, 1.16, 1.03 and 1.00 times higher SOC content respectively compared to soil under cropland use. Thus, the measured SOC contents of cropland in the present study were multiplied by these depth-specific factors and the grassland model run on this adjusted dataset. The resulting predictions ( $\left.\widehat{P D}_{\text {adj.crop }}\right)$ were assumed to resemble $P D_{\text {crop }}$ without tillage, as well as similar trafficking practices (man) and SOC content (use) as in the grassland reference. Thus,

$\widehat{P D}_{\text {adj.crop }}=P D_{\text {crop }}-$ use - man

Finally, use was quantified by merging Eq. 5 with Eq. 7:

use $=\widehat{P D}_{\text {crop }}-\widehat{P D}_{\text {adj.crop }}$

$$
=\left(P D_{\text {crop }}-\widehat{P D}_{\text {adj.crop }}\right)-\left(P D_{\text {crop }}-\widehat{P D}_{\text {crop }}\right)
$$

Thus the change of soil compactness due to SOC loss (use) was quantified by comparing the residuals of $\widehat{P D}_{\text {adj.crop }}$ with the residuals of $\widehat{P D}_{\text {crop }}$ (Fig. 1, purple area).

The natural (management and land use-independent) compactness of a given cropland site $i\left(P D_{\text {ref, } i}\right)$ was calculated as

$P D_{\mathrm{re} f, i}=P D_{i}-\overline{u s e}-\overline{m a n}$

where $P D_{i}$ represents the measured PD of site $i$, $\overline{u s e}$ denotes the average use- and $\overline{\text { man }}$ the average maneffect of all cropland sites. If $P D_{\text {ref, } i}>1.75 \mathrm{~g} \mathrm{~cm}^{-3}$ (Table 1), severe soil compactness was assumed to be of 


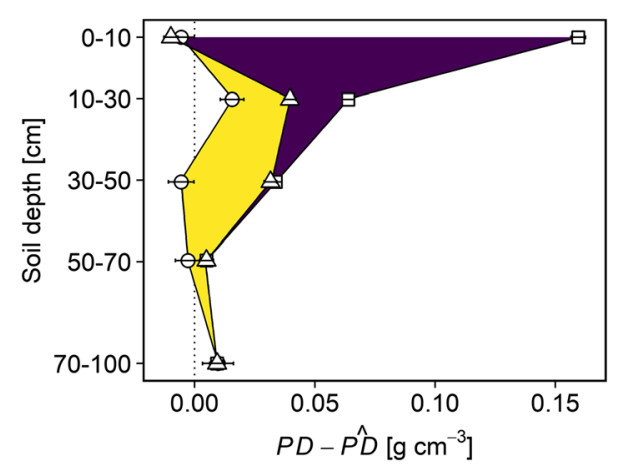

Compaction caused by

Land use (SOC loss)

Management (traffic)

\section{Residuals}

-O- Permanent grassland (reference)

$\triangle$ Cropland

$\neg-$ Adjusted cropland
Fig. 1 Comparison of measured packing densities $(P D)$ and predicted packing densities $(P D)$, i.e. residuals, by depth. All predictions were derived from one Random Forest model, which was calibrated only on permanent grassland $\left(\mathrm{R}^{2}=0.77\right)$. For

pedogenic or geogenic origin. If $P D_{\text {ref, } i}<1.75 \mathrm{~g} \mathrm{~cm}^{-3}$ and $P D_{\text {ref }, i}+\overline{m a n}>1.75 \mathrm{~g} \mathrm{~cm}^{-3}$, severe soil compactness was assumed to be management derived (compaction due to tillage/trafficking). If $P D_{r e f, i}<1.75 \mathrm{~g} \mathrm{~cm}^{-3}$ and $P D_{\text {ref }, i}+\overline{u s e}>1.75 \mathrm{~g} \mathrm{~cm}^{-3}$, severe soil compactness was assumed to be land-use derived (compaction due to SOC loss). In the following, we define all soil layers with PD above the critical limit of $1.75 \mathrm{~g} \mathrm{~cm}^{-3}$ as "compacted" (see above) and refer to compression of soil from initially $\leq 1.75 \mathrm{~g} \mathrm{~cm}^{-3}$ to $>1.75 \mathrm{~g} \mathrm{~cm}^{-3}$ as "compaction".

\section{Statistics and software}

All data analysis was performed using R v 3.5.1 (R Core Team 2018) in RStudio v 1.1.456 (RStudio Team 2016). Random Forest models were built as implemented in the randomForestSRC package by Ishwaran and Kogalur (2018). To evaluate the accuracy of Random Forest models, root mean square errors (RMSE) and coefficients of determination $\left(\mathrm{R}^{2}\right)$ of out-of-bag estimates were reported, as described by Liaw and Wiener (2002). Variable importance was calculated after Breiman (2001). Those variables with greater importance than expected from a theoretical model in which all variables are equally important were considered influential (Hobley et al. 2015). The effect of influential variables on PD was illustrated in partial dependence plots. This illustrates the relationship between a predictor of interest and PD after adjusting PD for average effects of all other covariates included in the model (Hastie et al. 2009). All figures were created using the ggplot2 package (Wickham 2016). The same package was used for maps after converting data frames to permanent grassland, the out-of-bag residuals were plotted. For cropland, the original dataset (cropland) was used once and a modified dataset with adjusted soil organic carbon (SOC) contents (adjusted cropland) was used once

simple features (Pebesma 2018). The shapefile of German borders was downloaded from http://www. bkg.bund.de Mean values are represented as mean \pm standard error. Mann-Whitney-Wilcoxon Tests were used to test whether sample populations were identical. Differences were generally regarded as significant at $p$ values $<0.05$. If more than two populations were compared, Bonferroni correction was applied.

\section{Results}

Distribution and spatial extent of root-restricting layers

In $71 \%$ of all agricultural soils in Germany, potential rooting was restricted to less than $100 \mathrm{~cm}$ depth (Table 1; Fig. 2). Most RRLs (62\%) were classified as severe barriers to root elongation. Restrictions occurred mainly due to physical soil properties (Fig. 3a-e). Moderate and severe soil compactness limited rootability in $46 \%$, sandy subsoil in $12 \%$, rock fragments in $8 \%$, shallow bedrock in $6 \%$ and cemented layers in $2 \%$ of agricultural land. Chemical constraints to root growth occurred in $21 \%$ of all agricultural sites, with high groundwater levels affecting $14 \%$ and acidity $10 \%$ of all sites (Fig. 3f-g). Generally, RRLs occurred mostly in subsoils, i.e. in $>30 \mathrm{~cm}$ depth, but there was also a considerable number of sites (13\%) with potential limitations to root growth already occurring in topsoils. In cropland, restricted root growth in both the topsoil and subsoil was mostly caused by high compactness. In grassland, acidity was the dominant cause of root restriction in the topsoil, while anoxia was the dominant 
(a) Moderate or severe restriction

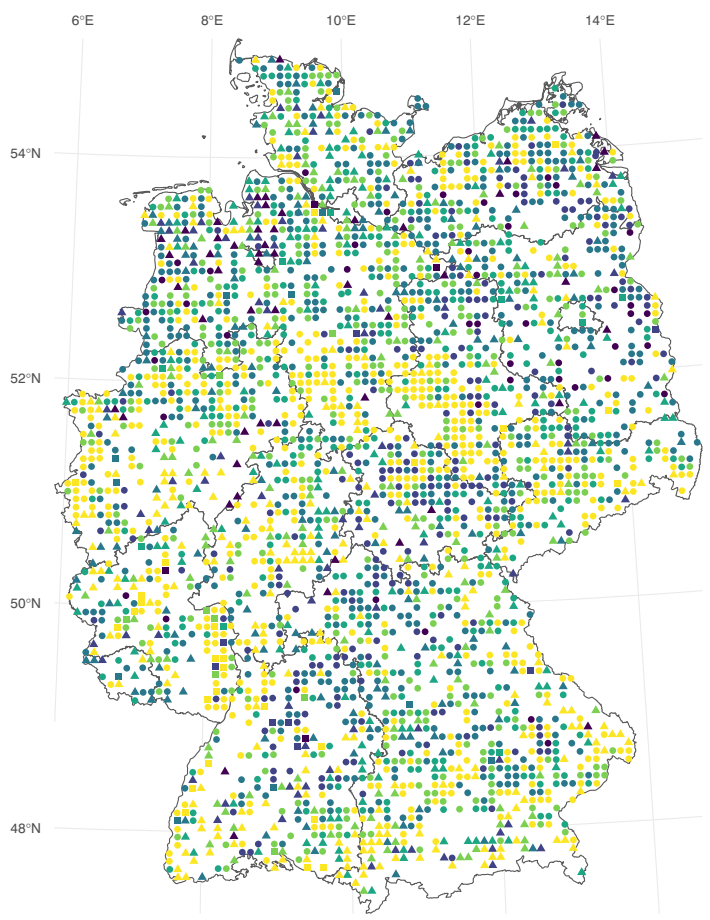

(b) Severe restriction

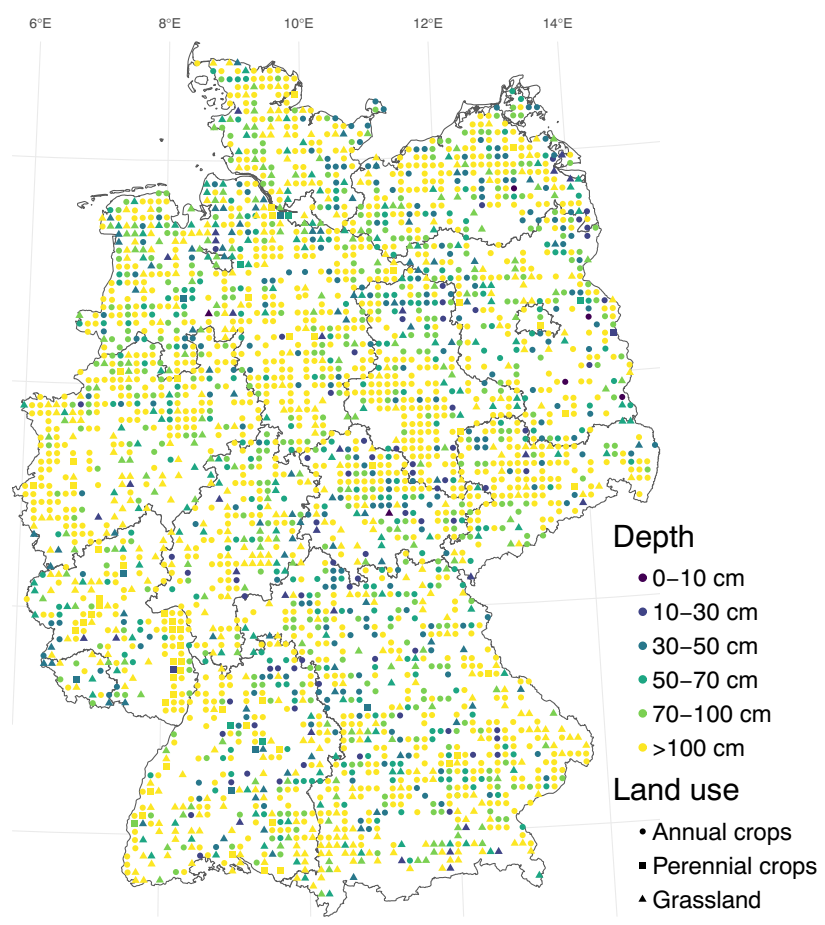

Fig. 2 Depth to uppermost root-restricting soil layer considering (a) all levels of root restriction and (b) severe root restriction only. Symbol shapes illustrate different land use

cause of root restriction in the subsoil due to high groundwater levels.

Compactness increased significantly with soil depth. While in $30-50 \mathrm{~cm}$ depth, $20 \%$ of all sites were compacted, this proportion increased to $33 \%$ in 70 $100 \mathrm{~cm}$ depth. Cropland was more densely packed than grassland (Fig. 4). This difference was most pronounced in 0-10 $\mathrm{cm}$ and decreased with depth. Sandy subsoil occurred mostly in northwest German lowlands on soils that had developed from Pleistocene sediments (Fig. 3e). In the same region, high acidity and, in a few cases, cementation restricted rootability (Fig. 3c, g). Most acid soils were either peatland and fens (42\%) or Podzols (20\%). Cementation was mostly of an ortsteinic $(83 \%)$ or petrogleyic $(6 \%)$ nature. Shallow bedrock frequently occurred in the peripheral regions of forested lower mountain ranges in central Germany and along the Jurassic in Swabia, southern Germany (Fig. 3a). Similar regions were characterised by high rock fragment contents (Fig. 3b). Permanent anoxic conditions were a common feature in riverine lowlands (river valleys of the Elbe, Weser and Ems), northwest coastal lowlands and floodplains south of the Danube river (Fig. 3f).
Effect of root-restricting layers on root distribution

Relative root counts were significantly lower in the presence of RRLs (Fig. 5). This was observed both in cropland with winter wheat (Fig. 5a) and in grassland (Fig. 5b). The differences were particularly pronounced when comparing relative root counts of severe RRLs to root counts in soil layers without RRLs. In 30-50 cm depth, relative root counts of winter wheat were $18 \%$ lower in the presence of severe RRLs at or above $30-50 \mathrm{~cm}$ depth compared to soils without RRLs. In grassland, relative root counts were $32 \%$ lower in the presence of severe RRLs at $30-50 \mathrm{~cm}$ depth. Moderate RRLs decreased relative root counts of winter wheat (grassland) by only $10 \%(9 \%)$ at $30-50 \mathrm{~cm}$ depth (not significant). This confirmed that severe RRLs decreased root elongation more than moderate RRLs. The observed differences in relativerootcounts between soil layers without, with moderate and with severe RRLs derived mostly from soil compactness as this was the dominant driver of root restriction in German agricultural soils. At 30-50 cm depth, severe soil compactness (PD $>1.82 \mathrm{~g} \mathrm{~cm}^{-3}$ ) decreased relative root counts of winter wheat by $16 \%$ (not significant) and in grassland 


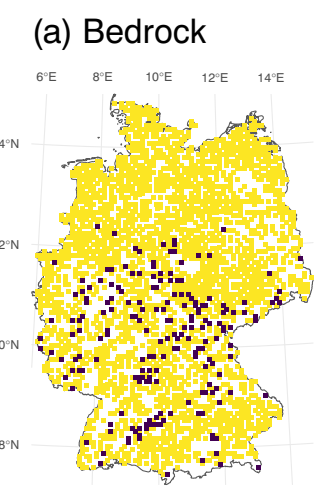

(c) Cementation

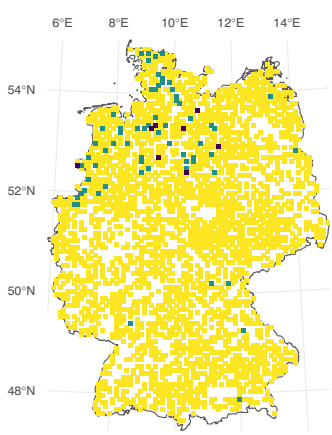

(e) Sandy subsoil

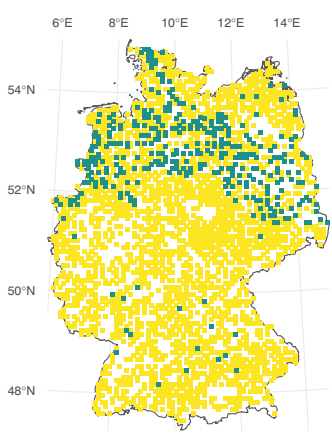

(g) Acidity

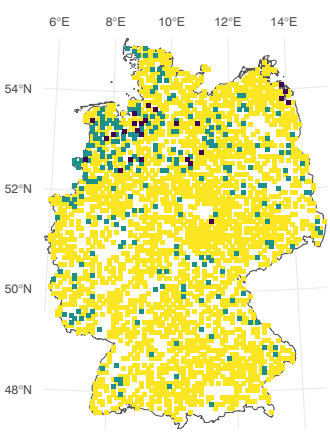

Fig. 3 Type and magnitude of root-restricting soil layers in $<100 \mathrm{~cm}$ depth (b) Rock fragments

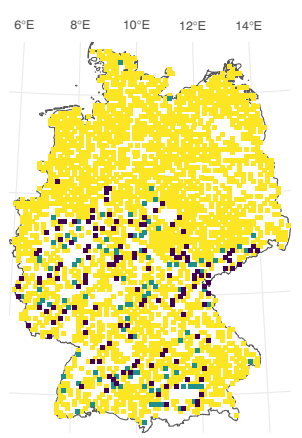

(d) Compactness

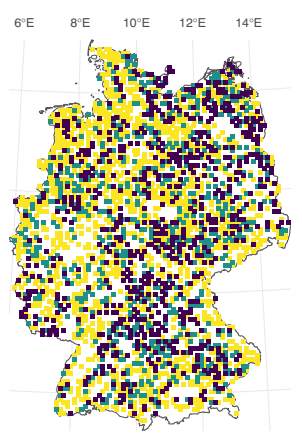

(f) Anoxia

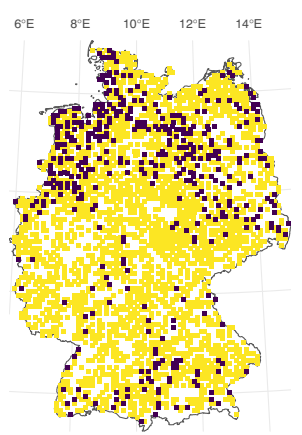

Root-restricting soil layer

None

- Moderate

- Severe by $29 \%$ compared to the respective references with low compactness $\left(\mathrm{PD}<1.75 \mathrm{~g} \mathrm{~cm}^{-3}\right.$ ).

Effect of root-restricting layers on grain yield of winter wheat

The average grain yield of winter wheat was $6 \%$ lower on sites with severe RRLs compared to reference sites without RRLs. On sites with moderate RRLs, the grain yield of winter wheat was 3\% lower (not significant). When evaluating all causes of RRLs together, differences in grain yield were independent of average soil texture in 0-100 cm (Fig. S 4). However, when evaluating grain yield only with respect to compactness, i.e. neglecting other causes of RRLs, differences in grain yield depended on soil texture: significant differences in grain yield among soils with low, with moderate and with severe degrees of compactness were only observed in soils with a coarse texture $(<17 \%$ clay). Here, severely compacted sites (PD> $1.82 \mathrm{~g} \mathrm{~cm}^{-3}$ ) showed 5\% lower grain yields compared to reference sites with low compactness $\left(\mathrm{PD}<1.75 \mathrm{~g} \mathrm{~cm}^{-3}\right.$ ). Yield losses on compacted, coarse-textured soil with RRLs were particularly pronounced in relatively dry growing seasons (Fig. 6). In relatively wet growing seasons, no significant differences were observed between compacted and non-compacted soil.

\section{Drivers of soil compactness}

All Random Forest models predicted PD with high accuracy and $\mathrm{R}^{2}$ ranging from 0.5 to 0.8 (Fig. 7 \& Fig. $\mathrm{S} 5$ ). Only for $0-10 \mathrm{~cm}$ in cropland was the accuracy of predicted PD values lower because of limited information on recent tillage practices $\left(\mathrm{R}^{2}=0.3\right)$. Overall, SOC was by far the most important variable for explaining PD (Fig. 7). However, the importance of SOC decreased with depth. In grassland, the importance of SOC in explaining PD decreased gradually with depth, while in cropland a sharp decrease was observed between the ploughed horizon and the subsoil below $30 \mathrm{~cm}$ (Fig. $\mathrm{S}$ 5). Partial dependence plots revealed a strongly negative relationship between $\mathrm{PD}$ and SOC, i.e. PD increasing with decreasing SOC (Fig. S 6A). This trend was stronger below 3\% SOC than above this threshold. In the subsoil, the relative importance of rock fragments and texture was similar to that of SOC in explaining PD. Above 5 vol-\% rock fragments, PD decreased strongly with increasing rock content, leading to low fine-soil PD 


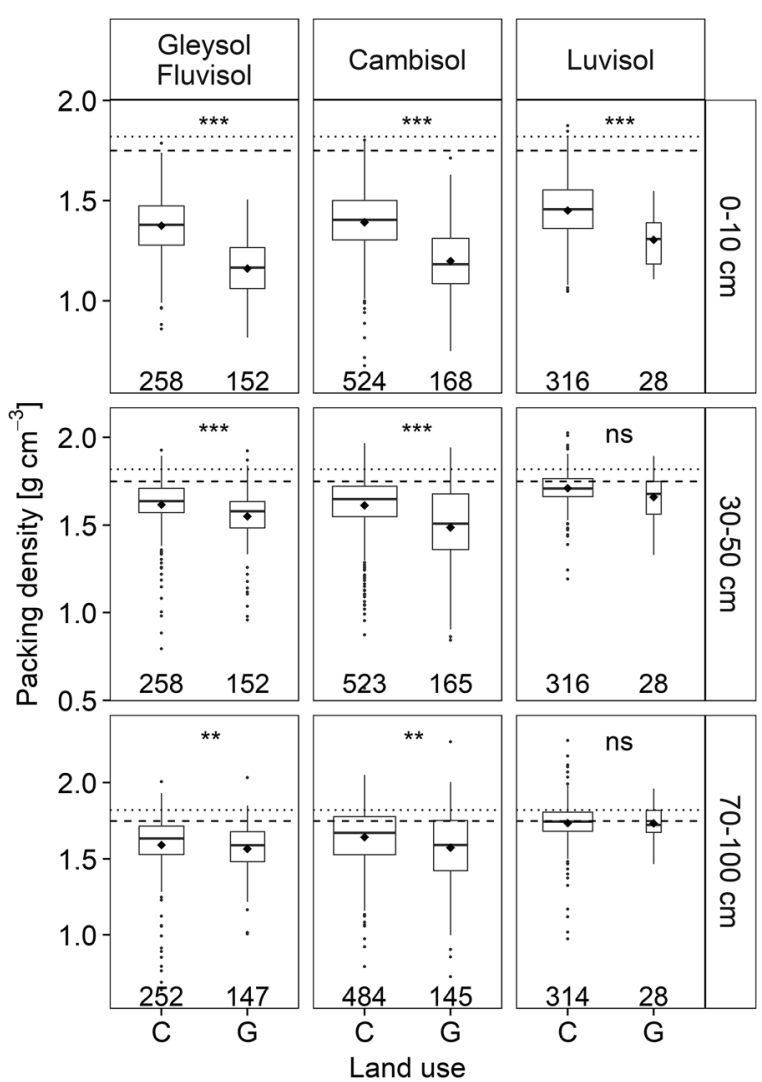

Fig. 4 Boxplots of packing density for annual crops (C) and grassland $(\mathrm{G})$ by sampling depth and soil type. Only the most common soil types (neglecting Anthrosols) and top, middle and lowest sampling depths are shown. Significance levels are illustrated as ns, *,** and *** for not significant, $p<0.05, p<0.01$ and $p<0.001$ respectively. Boxplot width is proportional to the observation number. Dashed and dotted lines represent moderate and severe threshold values for root restriction respectively

in stone-rich soils (Fig. S 6B). Clay was positively correlated with PD (Fig. S 6C).

The grassland (reference without anthropogenic increase in compactness) model underestimated measured cropland PD in 10-50 cm depth significantly, suggesting that at this depth increment PD of cropland was increased due to trafficking and tillage (Fig. 1, yellow area). This management effect was highest in $30-50 \mathrm{~cm}$ depth, where it increased the soil compactness of cropland by on average $0.04 \pm 0.006 \mathrm{~g} \mathrm{~cm}^{-3}$. Additionally, our analysis suggests considerable land use-induced increases in soil compactness due to conversion of natural vegetation to cropland (Fig. 1, purple area). Such land-use changes decrease the SOC content, which increases PD particularly in $0-10 \mathrm{~cm}$. Cropland soil in 0 $10 \mathrm{~cm}$ was $0.17 \pm 0.006 \mathrm{~g} \mathrm{~cm}^{-3}$ more densely packed than if the same site were used as grassland. Thus SOC loss increased soil compactness more than traffic. However, in topsoils compactness was mostly far below critical levels. Therefore, SOC loss (land use) pushed only a few sites beyond the chosen critical level of $1.75 \mathrm{~g} \mathrm{~cm}^{-3}$, and traffic (management) was identified as the dominant cause of anthropogenic soil compaction (Fig. 8). Overall, the area extent of anthropogenically compacted cropland, where land use and/or management increased the "natural", site-specific packing density $P D_{\text {ref }}$ above the chosen critical level of $1.75 \mathrm{~g} \mathrm{~cm}^{-3}$, was estimated to be $13 \%$ ( $10 \%$ due to traffic, $1 \%$ due to SOC loss, and $2 \%$ due to a combination of traffic and SOC loss). Anthropogenic soil compaction was only detectable above $50 \mathrm{~cm}$ depth.

\section{Discussion}

The root architecture of cultivated plants is genetically controlled (Lynch and Wojciechowski 2015), for example dicotyledonous plants such as alfalfa (Medicago sativa L.) tend to develop a deeper root system than monocotyledon (Materechera et al. 1992). However, root growth is highly responsive to its environment (Kolb et al. 2017). Therefore, the developmental plasticity of roots is considerable in soils. This has been confirmed in numerous studies (Wasson et al. 2014; Vetter and Scharafat 1964). It is widely agreed that certain soil properties restrict the root growth of most agricultural plants. However, reported threshold values to distinguish between root-restricting and not rootrestricting differ (Table 1). Based on the range of reported threshold values, soil layers were categorised into non-restricting, moderately root-restricting or severely root-restricting. Using root count data from profile walls, it was possible to validate this concept for winter wheat and grassland by showing significantly different rooting patterns among these three classes. This confirms the direct impact of RRLs on the rooting depth of cultivated crops and grassland species in German agricultural soils.

\section{Natural and anthropogenic causes of restricted rooting}

Most RRLs could be attributed to pedogenic and geogenic constraints: rock fragment and sand content are determined by the soil parent material. Furthermore, 
(a) Winter wheat

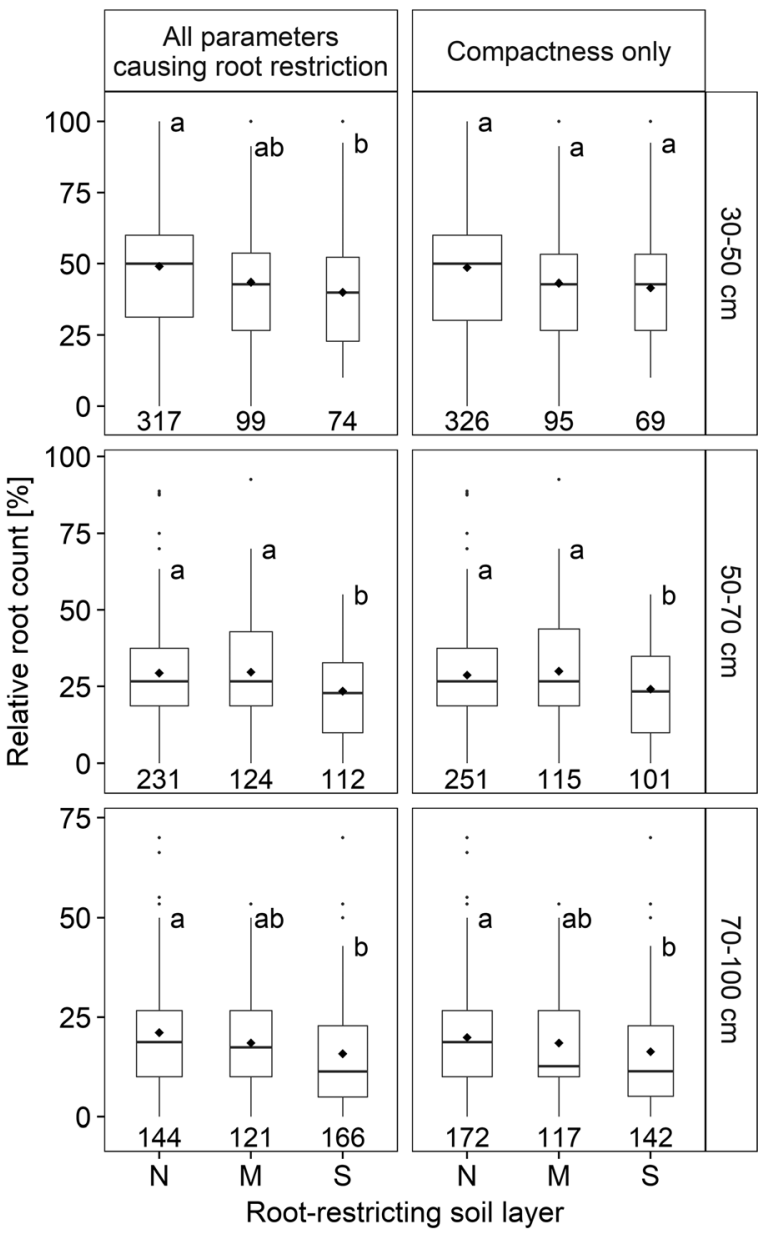

Fig. 5 Boxplot of relative root counts (root count in $0-10 \mathrm{~cm}$ divided by root count at depth ${ }_{i}$ ) for no $(\mathrm{N})$, moderate $(\mathrm{M})$ and severe (S) root-restricting soil layers. Root counts sharing the same

acid and cemented soil as well as shallow bedrock are primarily of pedogenic or geogenic origin. In some areas, pre-historic land use with heathland might have fostered podsolisation along with acidification and cementation (van Mourik et al. 2012). Historic periods of intense, land use-induced erosion on croplands might also have decreased the soil depth to bedrock (Bork and Lang 2003). However, the effect of prehistoric land use on present-day RRLs at national scale remains speculative and beyond the scope of this study. Here, the focus was on the role of modern agriculture in forming RRLs. In recent decades, the area extent of RRLs has frequently been assumed to have increased due to managementinduced compaction of cropland soils (Schjønning et al. 2015). However a distinction between "natural"

\section{(b) Grassland}
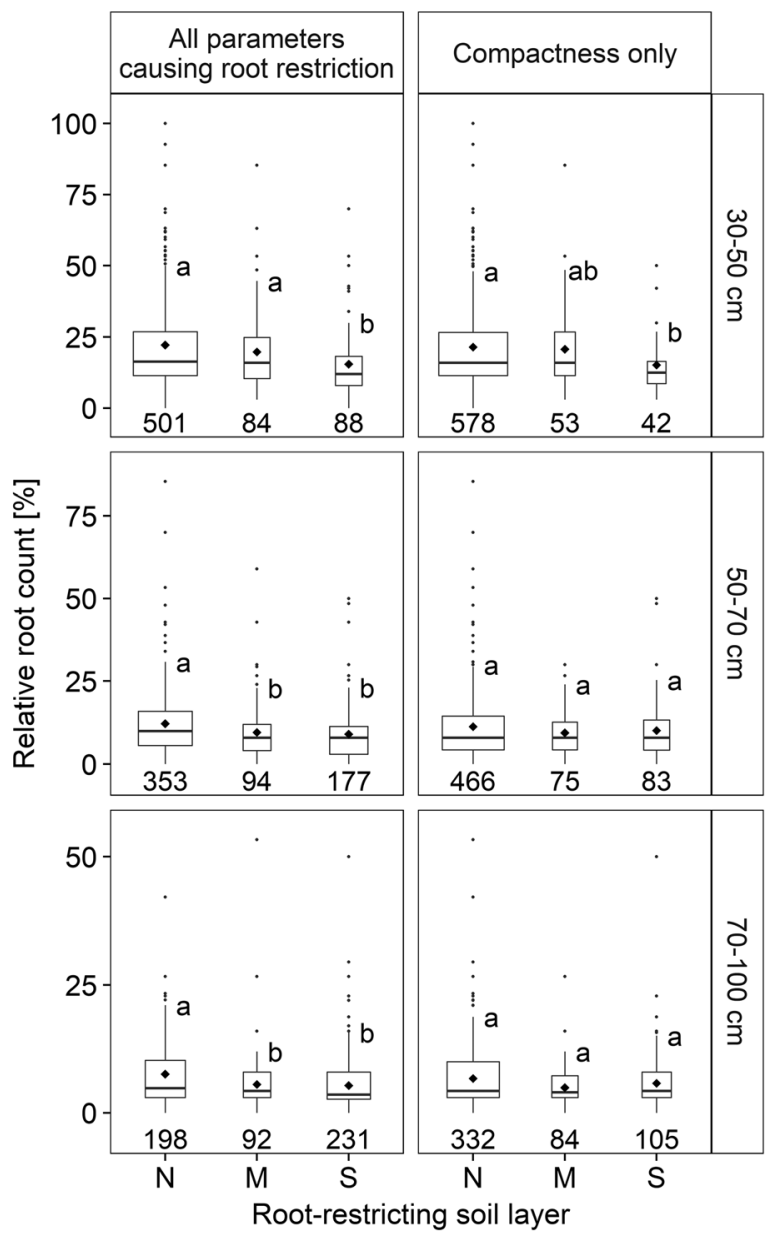

letter are not significantly different at $\mathrm{p}<0.05$ level. Boxplot width is proportional to the observation number

(geogenic, pedogenic and pre-historic) drivers of soil compactness and additional compaction by recent cropland use and management has rarely been made due to the methodological challenges this presents. There are three principal options for attributing changes in soil compactness to natural or anthropogenic causes and the most accurate one would be to study the evolution of soil compactness after conversion of natural vegetation to cropland over time. However, a long-term time series of this kind is not available for Germany. Another approach would be to assume that the area extent of naturally compacted land is negligible or confined to certain soil types only. In a recent study, Brus and van den Akker (2018) classified 43\% of the total land area in the Netherlands as compacted. This number was derived 


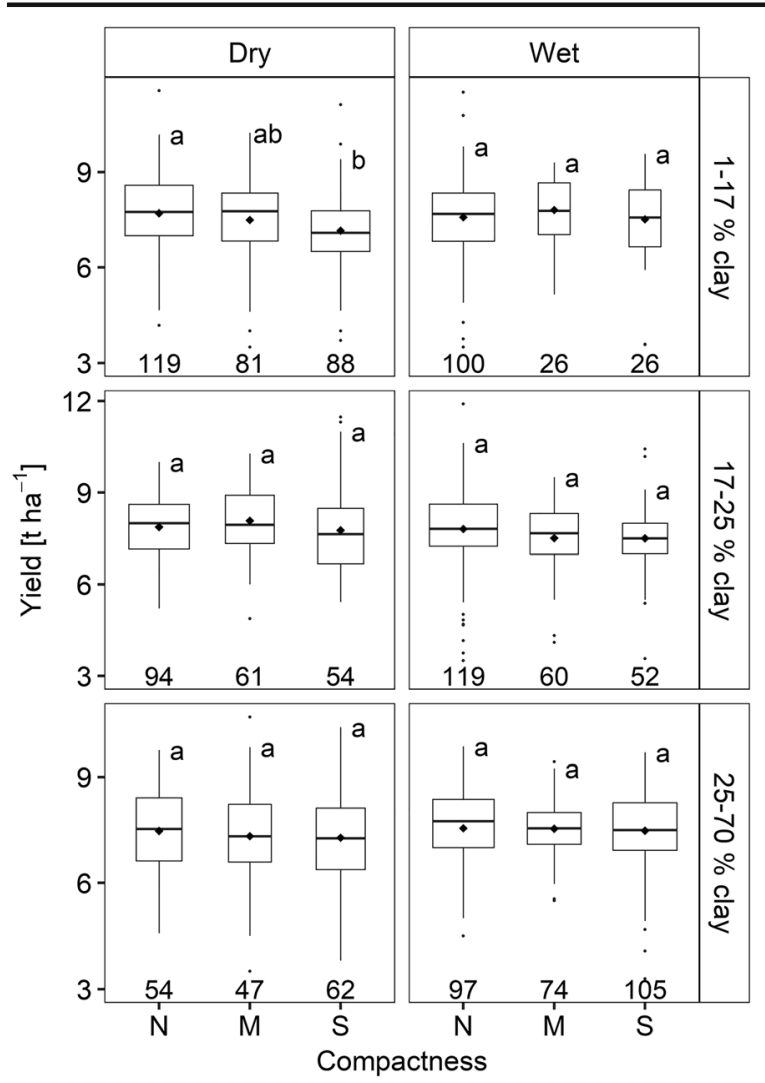

Fig. 6 Boxplot of grain yield for winter wheat grown on sites with no or low $(\mathrm{N})$, with moderate $(\mathrm{M})$ and with severe $(\mathrm{S})$ compaction stratified by precipitation (columns) and average clay content in 0 $100 \mathrm{~cm}$ depth (rows). Precipitation was classified as "dry" if cumulative precipitation in April, May and June was below median average $(171 \mathrm{~mm})$ and "wet" if it was above that value. Yields sharing the same letter are not significantly different at $p<0.05$ level. Boxplot width is proportional to the observation number

from bulk density, texture and SOC measurements directly below the ploughed layer of 128 sites. The authors distinguished between natural and anthropogenic soil compaction based on soil type. The only soil type that was regarded as naturally compacted made up $<1.5 \%$ of the study area (Brus and van den Akker 2017), while the remaining, vast majority of compacted land was assumed to be caused by "intensive use of heavy machines".

In the present study, significant effects of soil type on soil compactness were also observed. However, all mineral soil types featured a significant proportion of noncompacted sites. Thus, soil type alone did not suffice to differentiate between naturally compacted soil from anthropogenically compacted soil. Instead, these results suggest that in all soil types, traffic-induced soil compaction (man) only acts on top of the natural state of soil compactness $\left(P D_{\text {ref }}\right)$. This "natural" soil compactness is primarily controlled by SOC and rock content, texture and soil depth (Fig. 7). With increasing soil depth, the overburden pressure exerted by the soil column above increases (Gao et al. 2016), while root density and thus SOC content decreases. This explains why most (76\%) compacted sites showed maximum compactness at the maximum sampling depth of $70-100 \mathrm{~cm}$. If soil compaction were mostly caused by traffic, maximum compactness should occur in the uppermost soil layer, which is not being mechanically loosened (tilled) after trafficking, i.e. at $30-50 \mathrm{~cm}$ in cropland and $0-10 \mathrm{~cm}$ in permanent grassland. However, only $11 \%$ of all the compacted cropland and no compacted grassland showed maximum compactness at these depths. Thus the number of sites that were compacted in close proximity to wheels was much lower than the number of sites that were compacted in deep subsoil layers. This suggests that soil parent material and pedogenesis are important "natural" causes for the observed area extent of compacted agricultural sites. However, the mere comparison of soil compactness by depth did not suffice to quantify the area extent of naturally compacted soil. This was due to the unisotropic nature of agricultural soils. In particular, increasing rock content and buried, relictic topsoil often decreased soil compactness with depth. Therefore, decreasing compactness with depth could not be directly associated with traffic-induced soil compaction. If (i) soil is unisotropic, i.e. under field conditions, and (ii) compactness is not measured before potential anthropogenic compaction occurred, the quantification of anthropogenic compaction is only possible if the compactness of managed sites is compared to the compactness of non-managed reference sites with similar soil and site conditions. This is the third and final approach to differentiate between naturally compacted soil and anthropogenically compacted soil. Typically, such studies are based on a paired plot design in which the compactness of each plot of interest is related to its reference without anthropogenic changes in soil compactness. However, soil inventories, such as that developed in the present study, are not designed in paired plots and the possibilities of construing pairs retrospectively is limited. For example, the present study included far more potentially compacted sites (cropland) than non-compacted reference sites (permanent grassland). 
Fig. 7 Significant predictors of the packing density of mineral soils by depth. Brown and yellow colours represent pedology, grey geology and geomorphology, green represents land use and blue represents climate-related variables. Areas are proportional to the relative importance of the predictors. Each model is characterised by the number of observations in the training data ("n") and errors from out-of-bag data (root mean square error ("RMSE") and R-squared $\left(\right.$ (" $\left.R^{2 ")}\right)$ ). Positive marginal effects of continuous predictors on packing density are illustrated as "+" and negative effects as ".-"

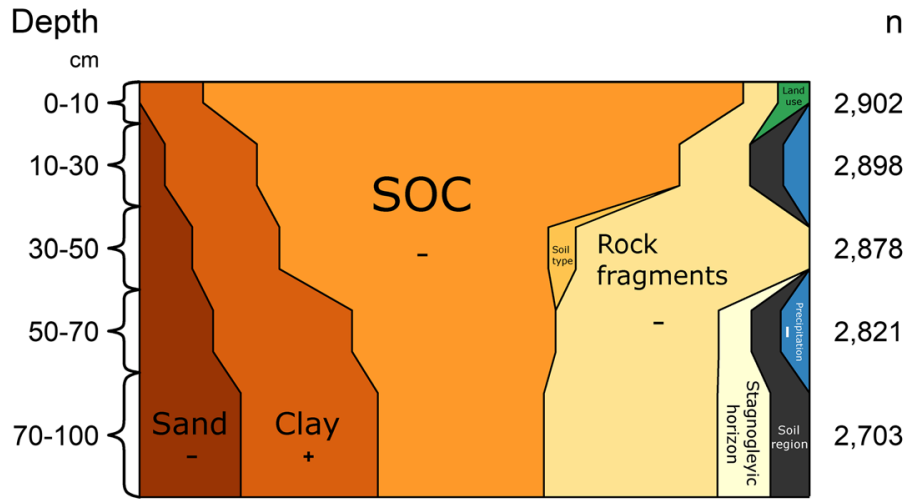

n RMSE $\mathrm{R}^{2}$ $\mathrm{g} \mathrm{cm}^{-3}$

0.130 .50

$0.11 \quad 0.57$

$0.12 \quad 0.55$

$0.13 \quad 0.52$

$0.14 \quad 0.51$

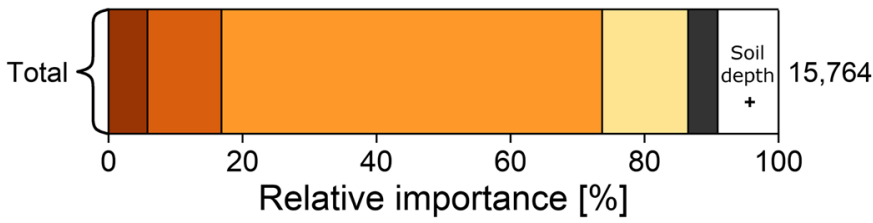

$0.11 \quad 0.72$
Also, average soil and site conditions between cropland and grassland differed (Schneider and Don 2019). However, grassland sites covered the full range of soil and site properties observed in cropland. Thus, the natural compactness of soil could be modelled based on the soil and site data from permanent grassland. This approach yielded a theoretical, but highly accurate reference for the measured compactness of cropland soil, and finally allowed a differentiation to be made between natural and anthropogenic causes of soil compression (Fig. 1). These results illustrate how the anthropogenic influence on soil compactness decreases with depth. Despite tillage (annual loosening), cropland use and management increased the compactness of topsoils
Fig. 8 Extent and cause of compacted $\left(>1.75 \mathrm{~g} \mathrm{~cm}^{-3}\right)$ depth increments in mineral soil profiles under cropland use.

Anthropogenic soil compaction was separated into land useinduced and/or managementinduced compaction. Sites (total) were classified as compacted if they showed at least one compacted soil layer. If there were different causes of soil compaction at a given site (e.g. management in $30-50 \mathrm{~cm}$ and pedology in 70-100 cm), only the uppermost compacted soil layer (management) was considered

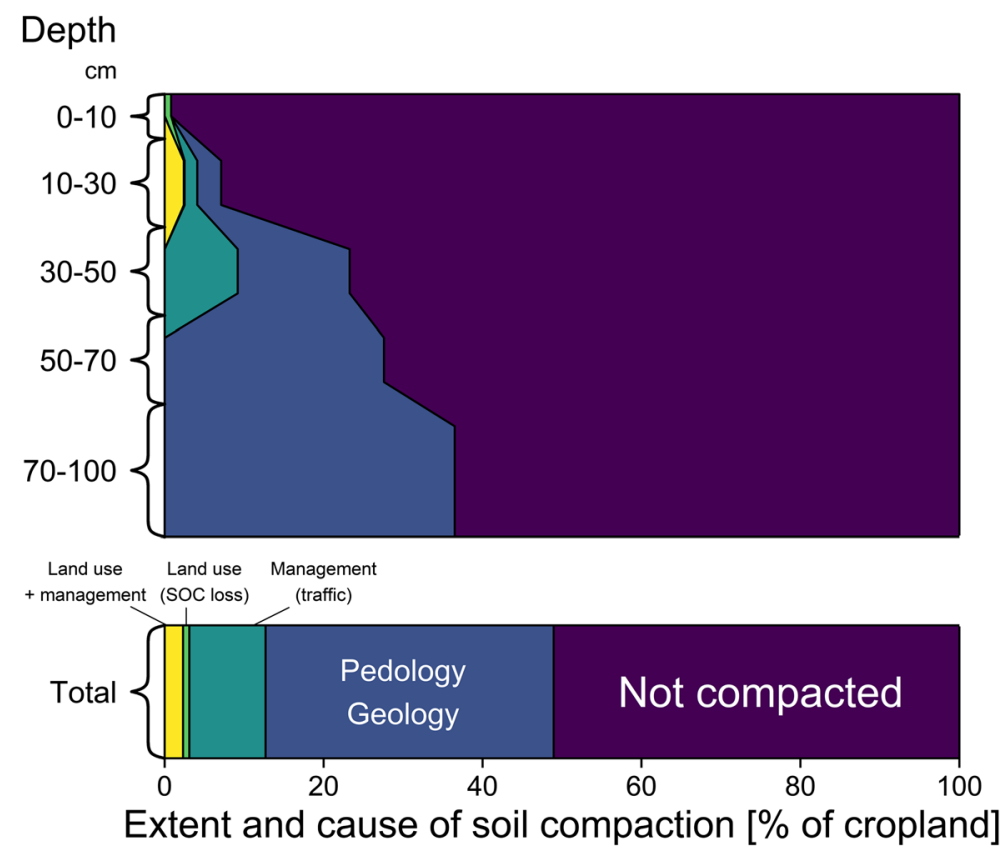


by up to $0.17 \pm 0.006 \mathrm{~g} \mathrm{~cm}^{-3}$. This can be attributed to traffic-induced pressure on soil, but also to the SOC deficit of cropland in comparison to potential natural vegetation (Poeplau and Don 2013).

SOC plays a key role in the aggregation of mineral soil particles. SOC loss can therefore cause the collapse of soil structure and soil compression (Soane 1990). However, in the topsoil, compactness was typically far below critical levels for restricting root growth. This explains why, despite the relatively large increases in soil compactness due to recent agricultural practices, only $4 \%$ of cropland was classified as compacted $\left(\mathrm{PD}>1.75 \mathrm{~g} \mathrm{~cm}^{-3}\right.$ ) in the topsoil (Fig. 8). In the uppermost subsoil layer directly below the ploughed topsoil, traffic increased the compactness of soil on average by $0.04 \pm$ $0.006 \mathrm{~g} \mathrm{~cm}^{-3}$. Although the land use and management-induced increase in soil compactness was much lower in the subsoil than in the topsoil, subsoil compression hindered soil functioning more than topsoil compression because the natural compactness of subsoil was closer to the critical level $\left(\mathrm{PD}=1.75 \mathrm{~g} \mathrm{~cm}^{-3}\right)$. Small increases in subsoil compactness were often sufficient to push compactness beyond this critical level for root growth. Beyond $50 \mathrm{~cm}$ depth, anthropogenic-induced increases in soil compactness decreased to non-significant levels. This is in good agreement with previous findings from controlled field experiments, where various traffic treatments did not compress soil beyond $60 \mathrm{~cm}$ depth (Håkansson and Reeder 1994; Schjønning and Rasmussen 1994). Traffic-induced soil compression to $90 \mathrm{~cm}$ depth as reported by Berisso et al. (2012) could not be confirmed in the present study. Overall, it was estimated that traffic and cropland use-induced SOC-loss together increased the natural compactness of $13 \%$ of German cropland beyond critical limits, i.e. PD > $1.75 \mathrm{~g} \mathrm{~cm}^{-3}$. This area estimate is in perfect agreement with official estimates by the German Environment Agency (UBA 2018). Based solely on expert judgments, the agency estimates the area extent of anthropogenically compacted cropland to be roughly $10-20 \%$. In the present study, a novel approach was developed to distinguish between natural and anthropogenic causes of soil compactness in regional soil inventories using machine learning. By adopting this approach in the first German agricultural soil inventory, recent expert judgments on the area extent of anthropogenically compacted cropland could be confirmed with field data.

Effect of root-restricting soil layers on crop yield

In the loess belt and lower Rhine valley, large areas of agricultural land were deep and fertile, with only sporadic occurrences of RRLs (Fig. 2). These regions have long been known for their fertility and remain the most productive thus far. In all other regions, physical or chemical barriers for root growth were common features of agricultural land. RRLs limit the availability of nutrient and water resources from deeper soil layers (Schneider et al. 2017; Unger 1979). Experimental field trials from different agro-ecological zones worldwide indicate that limited access to subsoil resources can cause severe yield losses, particularly under drought stress (Kirkegaard et al. 2007). The present study confirms that the adverse effects of RRLs on crop yield are not only detectable in controlled field trials and that they are relevant at national scale: the productivity of agricultural land with RRLs was significantly lower than on land without RRLs. This was despite potential differences in fertilisation, weather conditions, cultivars or pests and diseases, which were assumed to explain the high scatter in the yield data. Negative effects of RRLs on yield of winter wheat were greatest on coarsetextured soils. Coarse soils store less water and nutrients per unit volume than heavy soils. This means plants growing on coarse soils require a larger soil volume to accommodate nutritional needs compared to plants on heavy soil. Crop response to RRLs should thus depend on soil texture and yield losses increase with sand content. The present study confirms this hypothesis (Fig. 6). Considering negative yield effects of compaction were only observed under relatively dry growing conditions, highlights the importance of deep water resources for crop resilience. Changing precipitation patterns (Pfeifer et al. 2015) are likely to increase tomorrow's importance of subsoil water for plant growth. Thus, the observed adverse effects of RRLs on crop yield might intensify in future.

\section{Perspectives}

The extent and severity of anthropogenic soil compaction is subject to considerable public debate. For land evaluation purposes, soil compaction is typically assessed with respect to a critical level of soil compactness, beyond which soil functioning is assumed to be significantly constraint. The Joint Research Centre of 
the European Commission suggested a critical level of $1.75 \mathrm{~g} \mathrm{~cm}^{-3}$ for evaluating the PD of soils (Huber et al. 2008). This threshold value has also been used in the present study to distinguish between compacted (PD > $1.75 \mathrm{~g} \mathrm{~cm}^{-3}$ ) and non-compacted soil (PD $\leq$ $1.75 \mathrm{~g} \mathrm{~cm}^{-3}$ ). Classifying soil in compacted (restricted root growth) and non-compacted (non-restricted root growth) is a simplification since the response of root elongation to changes in soil compactness can be assumed to be continuous and not discrete. While literature generally confirms the presence of an optimum compactness for root growth and an asymptotical convergence of root growth to zero with increasing compactness (Fig. S 7), defining a threshold value which separates optimum from restricted root growth is arbitrary. For example, choosing a threshold value of $1.82 \mathrm{~g} \mathrm{~cm}^{-3}$ instead of $1.75 \mathrm{~g} \mathrm{~cm}^{-3}$ would have resulted in an area extent of $6 \%$ anthropogenically compacted cropland instead of $13 \%$. The effect of the chosen threshold value on the area estimates derived in the present study is illustrated in an interactive webgraphic (https://compact.shinyapps.io/play/). Arbitrary threshold values call for caution when comparing area estimates on soil compaction from different sources and they explain why any single area estimate on compacted cropland can only be a ballpark figure. For Germany, the present study confirms that anthropogenic compaction poses a significant threat to soil health constraining root growth as well as crop yield at roughly one out of ten unit areas of cropland. This calls for action. In order to prevent further spread of compacted cropland, farmer extension services and policy makers should continue to promote and support cautious trafficking practices (as little as possible; only when dry; low wheel loads; low tyre pressure; large wheel-soil contact area etc) along with all management practices that enrich SOC contents and prevent erosion of SOC-rich topsoil.

Compacted soil, may it be anthropogenic or pedogenic origin, along with high groundwater levels and soil acidity are the most important causes for restricted root elongation in German agricultural soils. Melioration measures, which improve access to subsoils and their resources could make future farming less vulnerable and more sustainable. By identifying where and why RRLs occur, this study shows potential target regions for future soil improvement (Part I). In Part II, different options for physical, chemical and/or biological soil improvement are discussed (Schneider and Don 2019).

\section{Conclusions}

The results of this study suggest that $71 \%$ of German agricultural land exhibits barriers for rooting. Most RRLs are of pedogenic and geogenic origin. However, a small, yet significant proportion of RRLs has been caused by human activities: land use and management can increase the compactness of soils beyond critical levels. It is estimated that trafficking, tillage-induced disturbance of soil structure and SOC losses have contributed to compact about one out of ten unit areas of German cropland to an extent that significantly restricts root growth.

Irrespective of their origin, RRLs limit the production capacity of agricultural land. Therefore, it is of considerable importance that the further spread of rootrestricting, compacted soil layers is prevented. Once they are established, melioration of RRLs is laborious and time-consuming (Schneider and Don 2019).

Acknowledgements This study made use of a dataset compiled by a large number of great people. We thank Anna Jacobs, Roland Prietz and Arne Heidkamp for their patience in answering numerous questions on the dataset and are grateful to Nellie Hobley and Cora Vos for their hints on using trees and forests for predictive modelling. Sören Gebbert calculated multi-annual mean NDVI indices from Landsat images. Christopher Poeplau, Catharina Riggers, Tamme de Vries, Sofia Heukrodt, Mirjam Helfrich, Fabian Kalks, Marco Lorenz, Joachim Brunotte and three anonymous reviewers made valuable comments on an earlier version of this manuscript. This study was part of the BonaRes research project Soil3 (grant number 031B0515E) funded by the Federal Ministry of Education and Research (BMBF) and of the German Agricultural Soil Inventory funded by the Federal Ministry of Food and Agriculture (BMEL).

Open Access This article is distributed under the terms of the Creative Commons Attribution 4.0 International License (http:// creativecommons.org/licenses/by/4.0/), which permits unrestricted use, distribution, and reproduction in any medium, provided you give appropriate credit to the original author(s) and the source, provide a link to the Creative Commons license, and indicate if changes were made.

\section{References}

AD-HOC-AG Boden (2005) Bodenkundliche Kartieranleitung, 5. Auflage. Schweizerbart, Stuttgart

Babalola O, Lal R (1977) Subsoil gravel horizon and maize root growth: II. Effects of gravel size, inter-gravel texture and natural gravel horizon. Plant Soil 347-357

Barber SA (1995) Soil nutrient bioavailability: a mechanistic approach. Wiley, New York 
Barraclough PB, Kuhlmann H, Weir AH (1989) The effects of prolonged drought and nitrogen fertilizer on root and shoot growth and water uptake by winter wheat. J Agron Crop Sci 163:352-360

Batey T (2009) Soil compaction and soil management - a review. Soil Use Manag 25:335-345

Batey T, McKenzie DC (2006) Soil compaction: identification directly in the field. Soil Use Manag 22:123-131

Bengough AG, McKenzie BM, Hallett PD, Valentine TA (2011) Root elongation, water stress, and mechanical impedance: a review of limiting stresses and beneficial root tip traits. J Exp Bot 62:59-68

Berisso FE, Schjønning P, Keller T, Lamandé M, Etana A, de Jonge LW, Iversen BV, Arvidsson J, Forkman J (2012) Persistent effects of subsoil compaction on pore size distribution and gas transport in a loamy soil. Soil Tillage Res 122: $42-51$

Biau G, Scornet E (2016) A random forest guided tour. TEST 25: 197-227

Bork H-R, Lang A (2003) Quantification of past soil erosion and land use / land cover changes in Germany. In: Lang A, Dikau R, Hennrich K (eds) Long term hillslope and fluvial system modelling: concepts and case studies from the Rhine River catchment. Springer, Berlin

Breiman L (2001) Random forests. Mach Learn 45:5-32

Brus DJ, van den Akker JJH (2017) Interactive comment on "how serious a problem is soil compaction in the Netherlands? A survey based on probability sampling" by dick J. Brus and Jan J. H. van den Akker. SOIL Discussions: C1-C2

Brus DJ, van den Akker JJH (2018) How serious a problem is subsoil compaction in the Netherlands? A survey based on probability sampling. SOIL 4:37-45

Chamen T, Alakukku L, Pires S, Sommer C, Spoor G, Tijink F, Weisskopf P (2003) Prevention strategies for field trafficinduced subsoil compaction: a review: part 2. Equipment and field practices. Soil Tillage Res 73:161-174

Core Team R (2018) R: a language and environment for statistical computing. R Foundation for Statistical Computing, Vienna

Cruse R, Cassel D, Averette F (1980) Effect of particle surface roughness on densification of coarse-textured soil. Soil Sci Soc Am J 44:692-697

da Silva AP, Kay B (1997) Estimating the least limiting water range of soils from properties and management. Soil Sci Soc Am J 61:877-883

Daddow RL, Warrington G (1983) Growth-limiting soil bulk densities as influenced by soil texture. Watershed Systems Development Group, USDA Forest Service Fort Collins

De Vos B, Van Meirvenne M, Quataert P, Deckers J, Muys B (2005) Predictive quality of Pedotransfer functions for estimating bulk density of Forest soils. Soil Sci Soc Am J 69: $500-510$

Destatis (2017a) Bodenbearbeitungsverfahren landwirtschaftlicher Betriebe auf Ackerflächen im Freiland 2015/16 sowie Ackerland ohne Fruchtwechsel von 2015 bis 2016 nach Größenklassen des Ackerlandes Statistisches Bundesamt (https://www.destatis.de/DE/Themen/BranchenUnternehmen/Landwirtschaft-ForstwirtschaftFischerei/Produktionsmethoden/Publikationen/DownloadsProduktionsmethoden/bodenbearbeitung-erosionsschutz- fruchtwechsel-5411209169004.pdf?_blob= publicationFile\&v $=3$ )

Destatis (2017b) Land- und Forstwirtschaft. Statistisches Jahrbuch - Deutschland und Internationales. Bundesministerium für Ernährung und Landwirtschaft (www.destatis.de/jahrbuch)

Destatis (2017c) Landwirtschaftliche Betriebe mit Bewässerungsmöglichkeit auf Freilandflächen - ohne Frostschutz - und bewässerte Fläche 2015 nach Größenklassen der landwirtschaftlich genutzten Flächen (LF) 2016. Tabelle 1202 R. Statistisches Bundesamt (https://www.destatis.de/DE/Themen/BranchenUnternehmen/Landwirtschaft-ForstwirtschaftFischerei/Landwirtschaftliche-Betriebe/ Publikationen/Downloads-LandwirtschaftlicheBetriebe/betriebe-bewaesserung-5411205169004.pdf? blob=publicationFile \&v=3)

Dexter AR (2004) Soil physical quality: part I. theory, effects of soil texture, density, and organic matter, and effects on root growth. Geoderma 120:201-214

Dunbabin V, Diggle EA, Rengel Z (2003) Is there an optimal root architecture for nitrate capture in leaching environments? Plant Cell Environ 26:835-844

DWD (2019) REGNIE grids of daily precipitation, last accessed: 10th May 2019. DWD Climate Data Center (CDC), Offenbach (https://opendata.dwd.de/climate environment/CDC/grids_germany/daily/regnie/)

GAFA (2014) Trockenrohdichte des Feinbodens $\left(\mathrm{TRD}_{\mathrm{FB}}\right)$ und Feinbodenvorrat (FBV) In: GF Analytik (ed) Handbuch Forstliche Analytik Eine Loseblatt-Sammlung der Analysemethoden im Forstbereich. Bundesministerium für Ernährung und Landwirtschaft, Berlin

Gao W, Hodgkinson L, Jin K, Watts CW, Ashton RW, Shen J, Ren T, Dodd IC, Binley A, Phillips AL, Hedden P, Hawkesford MJ, Whalley WR (2016) Deep roots and soil structure. Plant Cell Environ 39:1662-1668

Håkansson I, Reeder RC (1994) Subsoil compaction by vehicles with high axle load - extent, persistence and crop response. Soil Tillage Res 29:277-304

Hastie T, Tibshirani R, Friedman J (2009) The elements of statistical learning. Data mining, inference, and prediction. Springer, New York

Hengl T, de Jesus JM, Heuvelink GB, Gonzalez MR, Kilibarda M, Blagotić A, Shangguan W, Wright MN, Geng X, BauerMarschallinger B (2017) SoilGrids250m: global gridded soil information based on machine learning. PLoS One 12: e0169748

Hobley E, Wilson B, Wilkie A, Gray J, Koen T (2015) Drivers of soil organic carbon storage and vertical distribution in eastern Australia. Plant Soil 390:111-127

Huber S, Prokop G, Arrouays D, Banko G, Bispo A, Jones R, Kibblewhite M, Lexer W, Möller A, Rickson R (2008) Environmental assessment of soil for monitoring: volume I, indicators \& criteria. Office for the Official Publications of the European Communities, Luxembourg

Ishwaran H, Kogalur UB (2018) randomForestSRC: random forests for survival, regression and classification (RF-SRC). R package version 2.7 .0

Jacobs A, Flessa H, Don A, Heidkamp A, Prietz R, Dechow R, Gensior A, Poeplau C, Riggers C, Schneider F, Tiemeyer B, Vos C, Wittnebel M, Müller T, Säurich A, Fahrion-Nitschke A, Gebbert S, Hopstock R, Jaconi A, Kolata H, Lorbeer M, 
Schröder J, Laggner A, Weiser C, Freibauer A (2018) Landwirtschaftlich genutzte Böden in Deutschland Ergebnisse der Bodenzustandserhebung. Johann Heinrich von Thünen-Institut, Braunschweig

Jaconi A, Vos C, Don A (2019) Near infrared spectroscopy as an easy and precise method to estimate soil texture. Geoderma 337:906-913

Jin K, White PJ, Whalley WR, Shen J, Shi L (2017) Shaping an optimal soil by root-soil interaction. Trends Plant Sci 22: $823-829$

Jones CA (1983) Effect of soil texture on critical bulk densities for root growth. Soil Sci Soc Am J 47:1208-1211

Kaufmann M, Tobias S, Schulin R (2010) Comparison of critical limits for crop plant growth based on different indicators for the state of soil compaction. J Plant Nutr Soil Sci 173:573583

Kautz T, Amelung W, Ewert F, Gaiser T, Horn R, Jahn R, Javaux M, Kemna A, Kuzyakov Y, Munch J-C, Pätzold S, Peth S, Scherer HW, Schloter M, Schneider H, Vanderborght J, Vetterlein D, Walter A, Wiesenberg GLB, Köpke U (2013) Nutrient acquisition from arable subsoils in temperate climates: a review. Soil Biol Biochem 57:1003-1022

Kirkegaard JA, Lilley JM, Howe GN, Graham JM (2007) Impact of subsoil water use on wheat yield. Aust J Agric Res 58: 303-315

Kolb E, Legué V, Bogeat-Triboulot M-B (2017) Physical root-soil interactions. Phys Biol 14:065004

Kuhlmann H, Baumgärtel G (1991) Potential importance of the subsoil for the $\mathrm{P}$ and $\mathrm{mg}$ nutrition of wheat. Plant Soil 137: $259-266$

Kuhlmann H, Barraclough PB, Weir AH (1989) Utilization of mineral nitrogen in the subsoil by winter wheat. $\mathrm{Z}$ Pflanzenernähr Bodenkd 152:291-295

Kutschera L, Lichtenegger E, Sobotik M (2009) Wurzelatlas der Kulturpflanzen gemäßigter Gebiete mit Arten des Feldgemüsebaues. DLG-Verlag, Frankfurt am Main

Leenaars JGB, Claessens L, Heuvelink GBM, Hengl T, Ruiperez González M, van Bussel LGJ, Guilpart N, Yang H, Cassman KG (2018) Mapping rootable depth and root zone plantavailable water holding capacity of the soil of sub-Saharan Africa. Geoderma 324:18-36

Liaw A, Wiener M (2002) Classification and regression by randomForest. $\mathrm{R}$ news 2:18-22

Lipiec J, Siczek A, Sochan A, Bieganowski A (2016) Effect of sand grain shape on root and shoot growth of wheat seedlings. Geoderma 265:1-5

Lüttger AB, Feike T (2018) Development of heat and drought related extreme weather events and their effect on winter wheat yields in Germany. Theor Appl Climatol 132:15-29

Lynch JP (2013) Steep, cheap and deep: an ideotype to optimize water and $\mathrm{N}$ acquisition by maize root systems. Ann Bot 112: $347-357$

Lynch JP, Wojciechowski T (2015) Opportunities and challenges in the subsoil: pathways to deeper rooted crops. J Exp Bot 66: 2199-2210

Lynch J, Marschner P, Rengel Z (2012) Effect of internal and external factors on root growth and development. In: Marschner P (ed) Marschner's mineral nutrition of higher plants. Elsevier, San Diego
Madsen HB (1985) Distribution of spring barley roots in Danish soils, of different texture and under different climatic conditions. Plant Soil 88:31-43

Materechera SA, Alston AM, Kirby JM, Dexter AR (1992) Influence of root diameter on the penetration of seminal roots into a compacted subsoil. Plant Soil 144:297-303

Mueller L, Schindler U, Behrendt A, Eulenstein F, Dannowski R, Schlindwein SL, Shepherd TG, Smolentseva E, Rogasik J (2007) The Muencheberg soil quality rating (SQR): field manual for detecting and assessing properties and limitations of soils for cropping and grazing. Report, Leibniz-Zentrum für Agrarlandschaftsforschung (ZALF), Müncheberg

Naderi-Boldaji M, Weisskopf P, Stettler M, Keller T (2016) Predicting the relative density from on-the-go horizontal penetrometer measurements at some arable top soils in northern Switzerland. Soil Tillage Res 159:23-32

Oldeman LR, Hakkeling RTA, Sombroek WG (1991) World map of the status of human-induced soil degradation: an explanatory note. Global Assessment of Soil Degradation (GLASOD), International Soil Reference and Information Centre (ISRIC), United Nations Environment Programme (UNEP), Wageningen, Nairobi

Pebesma E (2018) Sf: simple features for R. R package version $0.6-3$

Pfeifer S, Buelow K, Gobiet A, Haensler A, Mudelsee M, Otto J, Rechid D, Teichmann C, Jacob D (2015) Robustness of ensemble climate projections analyzed with climate signal maps: seasonal and extreme precipitation for Germany. Atmosphere 6:677-698

Poeplau C, Don A (2013) Sensitivity of soil organic carbon stocks and fractions to different land-use changes across Europe. Geoderma 192:189-201

Poeplau C, Kätterer T (2017) Is soil texture a major controlling factor of root:shoot ratio in cereals? Eur J Soil Sci 68:964970

Renger M, Bohne K, Wessolek G (2014) Bestimmung und Aussagemöglichkeiten der effektiven Lagerungsdichte. In: Wessolek G, Kaupenjohann M, Renger M (eds) Bodenphysikalische Kennwerte und Berechnungsverfahren für die Praxis, Teil II. TU Berlin, Berlin

RStudio Team (2016) RStudio: integrated development environment for R. RStudio, Inc., Boston

Schjønning P, Rasmussen KJ (1994) Danish experiments on subsoil compaction by vehicles with high axle load. Soil Tillage Res 29:215-227

Schjønning P, van den Akker JJH, Keller T, Greve MH, Lamandé M, Simojoki A, Stettler M, Arvidsson J, Breuning-Madsen H (2015) Driver-pressure-state-impact-response (DPSIR) analysis and risk assessment for soil compaction - a European perspective. In: Sparks DL (ed) Advances in agronomy. Academic Press

Schneider F, Don A (2019) Root restricting layers in German agricultural soils. Part II: adaptation and melioration strategies. Plant Soil. https://doi.org/10.1007/s11104-019-04186-8

Schneider F, Don A, Hennings I, Schmittmann O, Seidel SJ (2017) The effect of deep tillage on crop yield - what do we really know? Soil Tillage Res 174:193-204

Schoeneberger P, Wysocki D, Busskohl C, Libohova Z (2017) Landscapes, Geomorphology, and Site Description. In: C Ditzler, K Scheffe, HC Monger (eds) Soil survey manual. 
USDA Handbook 18. Government Printing Office, Washington, D.C.

Slattery W, Conyers M, Aitken R (1999) Soil pH, aluminium, manganese and lime requirement. In: K Peverill, L Sparrow, D Reuter (eds) Soil analysis: an interpretation manual. CSIRO Publishing, Collingwood

Soane BD (1990) The role of organic matter in soil compactibility: a review of some practical aspects. Soil Tillage Res 16:179201

Soil Science Division Staff (2017) Examination and Description of Soil Profiles. In: C Ditzler, K Scheffe, HC Monger (eds) Soil survey manual. USDA Handbook 18. Government Printing Office, Washington, D.C.

Stahr K, Kandeler E, Herrmann L, Streck T (2016) Bodenkunde und Standortlehre. UTB

Statistisches Amt Mecklenburg-Vorpommern (2018) Wachstumsstand und Ernte - Ernteberichterstattung über Feldfrüchte und Grünland in Mecklenburg-Vorpommern. Statistisches Amt Mecklenburg-Vorpommern, Schwerin

Stirzaker RJ, Passioura JB, Wilms Y (1996) Soil structure and plant growth: impact of bulk density and biopores. Plant Soil 185:151-162

Tardieu F (1994) Growth and functioning of roots and of root systems subjected to soil compaction. Towards a system with multiple signalling? Soil Tillage Res 30:217-243

Tullberg JN (2018) Developments in mechanization technology: controlled traffic farming. In: Chen $\mathrm{G}$ (ed) Advances in agricultural machinery and technologies. CRC Press, Boca Raton

UBA (2018) Daten zur Umwelt. Umwelt und Landwirtschaft. Umweltbundesamt, Dessau-Roßlau

Unger PW (1979) Effects of deep tillage and profile modification on soil properties, root growth, and crop yields in the United States and Canada. Geoderma 22:275-295

Valentine TA, Hallett PD, Binnie K, Young MW, Squire GR, Hawes C, Bengough AG (2012) Soil strength and macropore volume limit root elongation rates in many UK agricultural soils. Ann Bot 110:259-270

van Breemen N, Buurman P (1998) Dense and cemented horizons: Fragipan and Duripan. In: van Breemen N, Buurman P (eds) Soil formation. Springer, Dordrecht van Mourik JM, Seijmonsbergen AC, Slotboom RT, Wallinga J (2012) Impact of human land use on soils and landforms in cultural landscapes on aeolian sandy substrates (Maashorst, SE-Netherlands). Quat Int 265:74-89

van Ouwerkerk C, Soane BD (1994) Conclusions and recommendations for further research on soil compaction in crop production. Dev Agric Eng 11:627-642

Vetter H, Scharafat S (1964) Root distribution of crop plants in subsoil. Zeitschrift für Acker-und Pflanzenbau 120:275-298

Vorderbrügge T, Brunotte J (2011) Mechanische Verdichtungsempfindlichkeit für Ackerflächen (Unterboden) - Validierung von Pedotransferfunktionen zur Ableitung der Verdichtungsempfindlichkeit bzw. zur Ausweisung "sensibler Gebiete" in Europa und ein praxisorientierter Lösungsansatz zur Guten fachlichen Praxis : Teil III: Ausweisung von "Risiko Gebieten" auf Basis von Pedotransferfunktionen - die aktuelle Situation in Europa. Landbauforschung = Applied agricultural and forestry research : journal of applied research in agriculture and forestry $61: 41-50$

Walter K, Don A, Tiemeyer B, Freibauer A (2016) Determining soil bulk density for carbon stock calculations: a systematic method comparison. Soil Sci Soc Am J 80:579-591

Wasson AP, Rebetzke GJ, Kirkegaard JA, Christopher J, Richards RA, Watt M (2014) Soil coring at multiple field environments can directly quantify variation in deep root traits to select wheat genotypes for breeding. J Exp Bot 65:62316249

Wickham H (2016) ggplot2: elegant graphics for data analysis. Springer, New York

WRB (2014) World Reference Base for Soil Resources 2014. World Soil Resources Reports No. 106. IUSS Working Group. FAO, Rome

Publisher's note Springer Nature remains neutral with regard to jurisdictional claims in published maps and institutional affiliations. 